\title{
Morphological Redescriptions of Three Condylostoma Ciliates (Heterotrichida: Condylostomatidae) New to Korea
}

\author{
Ji Hye Kim, Seok Won Jang, Mann Kyoon Shin* \\ Department of Biological Science, College of Natural Sciences, University of Ulsan, Ulsan 680-749, Korea
}

\begin{abstract}
Heterotrichous ciliates were isolated from marine and brackish habitats in Korea, and their morphology, infraciliature and morphometrical characters were investigated using silver impregnated methods. These three Condylostoma species were identified as Condylostoma curva Burkovsky, 1970, C. minutum Bullington, 1940 and C. spatiosum Ozaki and Yagiu in Yagiu, 1944. The species of Condylostoma based on morphology are highly variable in most of characters and distinguished as following. Condylostoma curva is oval to elongate ellipsoidal, size about $245 \times 100 \mu \mathrm{m}$ in vivo, and conspicuously dark greenish brown with cortical granules on their surface, buccal cavity relatively large about $40 \%$ of body length, 5-11 macronuclear nodules, 4-8 frontal cirri serially arranged and 22-38 somatic kineties. Condylostoma minutum is elongate ellipsoidal and the size about $310 \times 55 \mu \mathrm{m}$ in vivo, buccal field about $35 \%$ of body length, 12-20 macronuclear nodules, adoral zone consisted of 82-107 membranelles, large and long one frontal cirrus and 38-44 somatic kineties. Condylostoma spatiosum is large elongate ellipsoidal, size about $670 \times 105 \mu \mathrm{m}$ in vivo, buccal cavity about $25 \%$ of body length, 11-25 macronuclear nodules, 111-144 adoral membranelles, membrane-like 2 frontal cirri, 49-74 somatic kineties. These three Condylostoma species are described here for the first time in Korea.
\end{abstract}

Keywords: Condylostoma, marine, brackish water, redescription, heterotrichs, morphology, ciliate

\section{INTRODUCTION}

The genus Condylostoma is one of the well-known heterotrichous taxa that has a large body size and a pouch-like cell shape. The members of Condylostoma are found in marine and brackish water, freshwater and terrestrial habitats. Since being established the genus Condylostoma, more than 30 species have been described and only several species among them described by silver impregated methods (Kahl, 1932; Bullington, 1940; Villeneuve-Brachon, 1940; Yagiu, 1944; Bock, 1955; Fauré-Fremiet, 1958; Dragesco, 1960; Burkovsky, 1970; Hartwig, 1973; Dragesco and Dragesco-Kernéis, 1986; Carey, 1992; Foissner, 1995; Petz et al., 1995; Al-Rasheid, 1999; Foissner et al., 1999; Song et al., 2003; Shao et al., 2006; Chen et al., 2007). Their morphological characters are indistinctive for species identification because almost all characters have high variations in each species (e.g., body size, number of somatic kineties, ratio of oral field) (Song et al., 2003; Shao et al., 2006; Chen et al., 2007). In the present work, we redescribe three Condylostoma species, C. curva Burkovsky, 1970, C. minutum Bullington, 1940 and C. spatiosum Ozaki and Yagiu in Yagiu, 1944 isolated for the first time from saline waters in Korea.

\section{MATERIALS AND METHODS}

\section{Sample collection and enrichment}

Three Condylostoma species were collected from saline waters in Korea: C. curva was collected in November, 2011, marine water (salinity 35\%o) from littoral zone with some algae at Jukbyeon-ri, Jukbyeon-myeon, Uljin-gun, Gyeongsangbuk-do $\left(37^{\circ} 03^{\prime} 32^{\prime \prime} \mathrm{N}, 129^{\circ} 25^{\prime} 44^{\prime \prime} \mathrm{E}\right)$. Condylostoma minutum in October, 2011 stagnant marine water (salinity $30 \%$ ) on the rock with some debris at Pyoseon-ri, Pyoseonmyeon, Seogwipo-si, Jeju-do ( $\left.33^{\circ} 19^{\prime} 22^{\prime \prime} \mathrm{N}, 126^{\circ} 50^{\prime} 45^{\prime \prime} \mathrm{E}\right)$.

\footnotetext{
(c) This is an Open Access article distributed under the terms of the Creative Commons Attribution Non-Commercial License (http://creativecommons.org/ licenses/by-nc/3.0/) which permits unrestricted non-commercial use, distribution, and reproduction in any medium, provided the original work is properly cited.

pISSN 2234-6953 eISSN 2234-8190
}

*To whom correspondence should be addressed

Tel: 82-52-259-2396, Fax: 82-52-259-1694

E-mail: mkshin@ulsan.ac.kr 
Condylostoma spatiosum in January, 2008 brackish water (salinity 5\%o) of riverine with twigs, leaves, wood and some sand at the Taehwagang River, Taehwa-dong, Jung-gu, Ulsan $\left(35^{\circ} 33^{\prime} 06^{\prime \prime} \mathrm{N}, 129^{\circ} 17^{\prime} 04^{\prime \prime} \mathrm{E}\right)$.

The ciliates samples were delivered to the lab and transferred to a Petri dish ( $87 \mathrm{~mm}$ in diameter). These ciliates were cultured at room temperature enriched with dried wheat grain which provided for fungal and bacterial nutrients.

\section{Morphological observation and identification}

The morphology and behavior of living specimens were observed under a stereo microscope (Olympus SZH10; Olympus, Tokyo, Japan; Leica WILD M8; Leica Instruments, Inc., Exton, PA, USA) and an optical microscope (Axio Imager A1; Carl Zeiss, Oberkochen, Germany) at low (50-400 $\times$ ) and high $(1,000 \times$; immersion oil) magnifications using a DIC device. The living images were captured using a CCD camera (Axio Cam MRc; Carl Zeiss). The infraciliatures were observed using silver impregnated specimens by the protargol method (Wilbert, 1975; Foissner, 1992). Terminology and taxonomic classification followed Chen et al. (2007), Lynn (2008), and Shao et al. (2006).

\section{SYSTEMATIC ACCOUNTS}

Phylum Ciliophora Doflein, 1901

Subphylum Postciliodesmatophora Gerassimova and Servin, 1976

Class Heterotrichea Stein, 1859

Order Heterotrichida Stein, 1859

1 *Family Condylostomatidae Kahl in Doflein and Reichenow, 1929

2*Genus Condylostoma Bory de Saint-Vincent, 1824

3*Condylostoma curva Burkovsky, 1970

(Table 1, Figs. 1, 2)

Condylostoma curva Burkovsky, 1970: 58; Song et al., 2003: 457.

Condylostoma arenarium: Kahl, 1932: 455 (fig. 6 only); Dragesco and Dragesco-Kernéis, 1986: 393.

Material examined. Thirteen living and 22 protargol impregnated specimens were observed respectively and analyzed biometrically.

Diagnosis. Body size about $245 \times 100 \mu \mathrm{m}$ in vivo, oval to elongated ellipsoidal shaped, buccal cavity about $40 \%$ of body length, macronuclear moniliform with 5-11 nodules, yellowish brown cytoplasm, dark greenish brown cortical granules, 80-112 adoral membranelles, 4-8 frontal cirri, 2238 somatic kineties.

Description. Body size 210-285 × 70-125 $\mu \mathrm{m}$, usually about $245 \times 100 \mu \mathrm{m}$ in vivo (Table 1 ). Shape elongated ellipsoidal, dorsoventrally slightly flattened, anterior end truncated and slanted left side, posterior end gradually tapered and narrowly rounded, widest in mid-body (Figs. 1A, 2A). Oral cavity fairly deep with transversely striated inner wall (Fig. 2E). Macronucleus aligned with the right margin of the body, distinctly nodulated and connected by fine threads, composed of 5-11 usually 8 nodules with many small nucleoli, anteriormost macronuclear nodule size about $25 \times 15 \mu \mathrm{m}$ in impregnated preparations (Figs. 1A, C, 2B, J). No contractile vacuole. Cortex very flexible and contractile. Dark greenish brown cortical granules ellipsoidal, size about $0.5-1 \mu \mathrm{m}$, arranged 13 irregular rows in between kineties (Figs. 1F, G, 2G, H, N). Cytoplasm slightly yellow with some lipid-like droplets and food vacuoles (Fig. 2A, B). Movement moderately slow, usually gliding on bottom.

Somatic kineties arranged longitudinally 22-38 rows, usually commenced near the buccal field, formed suture posteriorly, consisted of dikinetids and somatic cilia about $10 \mu \mathrm{m}$ long in vivo (Table 1, Figs. 1B, C, 2I, L). Four to eight frontal cirrus near apical end of right margin, on outside of buccal cavity and 15-20 $\mu \mathrm{m}$ long in vivo (Table 1, Figs. 1A, B, E, 2D, M).

The adoral zone of membranelles conspicuously covered the left side of buccal field, occupied $32-46 \%$ of the body length with the proximal portion extending spirally into the cytopharynx, consisting of 80-112 adoral membranelles (Table 1, Figs. 1A, B, E, 2C, F, K). The paroral membrane located on the inner side of buccal cavity, conspicuously long and smoothly undulated and composed of cilia about $25 \mu \mathrm{m}$ in length in vivo (Figs. 1A, E, 2C, K).

Distribution. Africa (Benin), Asia (China, Korea), Europe (Germany, Russia).

Remarks. The accurate identification of Condylostoma species is difficult because they have high variations in many characters, fewer unique characters, overlapping of characteristics in many features, and inappropriate literature caused by previous insufficient descriptions (Kahl, 1932; Bullington, 1940; Villeneuve-Brachon, 1940; Yagiu, 1944; FauréFremiet, 1958; Burkovsky, 1970; Dragesco and DragescoKernéis, 1986; Song et al., 2003; Shao et al., 2006; Chen et al., 2007).

We identified Condylostoma curva Burkovsky, 1970 based on three main characters of the body shape, the color of cortical granules and the pattern of frontal cirri. The original population of C. curva described by Burkovsky (1970) was 
Table 1. Morphometric data on Condylostoma curva, C. minutum, and C. spatiosum

\begin{tabular}{|c|c|c|c|c|c|c|c|c|c|}
\hline Characters & Species & Mean & Min & Max & Med & SD & SE & CV & $\mathrm{n}$ \\
\hline \multirow[t]{3}{*}{ Body, length in vivo $(\mu \mathrm{m})$} & C. curva & 244.2 & 210 & 285 & 236 & 24.73 & 6.86 & 10.12 & 13 \\
\hline & C. minutum & 314.7 & 264 & 390 & 307 & 36.41 & 8.35 & 11.57 & 19 \\
\hline & C. spatiosum & 671.1 & 480 & 800 & 700 & 94.28 & 22.22 & 14.05 & 18 \\
\hline \multirow[t]{3}{*}{ Body, width in vivo $(\mu \mathrm{m})$} & C. curva & 100.9 & 71 & 123 & 99 & 13.33 & 3.70 & 13.21 & 13 \\
\hline & C. minutum & 54.3 & 44 & 71 & 54 & 8.03 & 1.84 & 14.80 & 19 \\
\hline & C. spatiosum & 104.4 & 80 & 130 & 110 & 14.90 & 3.51 & 14.26 & 18 \\
\hline \multirow[t]{3}{*}{ Body, width/body, length in vivo (\%) } & C. curva & 42.1 & 25.4 & 56.4 & 41.9 & 8.96 & 2.49 & 21.29 & 13 \\
\hline & C. minutum & 17.9 & 13.0 & 26.3 & 17.3 & 3.63 & 0.83 & 20.36 & 19 \\
\hline & C. spatiosum & 15.8 & 11.8 & 20.8 & 15.9 & 2.86 & 0.67 & 18.14 & 18 \\
\hline \multirow[t]{3}{*}{ Body, width $(\mu \mathrm{m})$} & C. curva & 129.2 & 70 & 193 & 131 & 30.99 & 6.93 & 23.98 & 20 \\
\hline & C. minutum & 86.0 & 58 & 108 & 88 & 12.29 & 2.68 & 14.28 & 21 \\
\hline & C. spatiosum & 406.0 & 286 & 540 & 374 & 90.02 & 34.02 & 22.17 & 11 \\
\hline \multirow[t]{3}{*}{ Body, length $(\mu \mathrm{m})$} & C. curva & 261.9 & 157 & 373 & 262.5 & 55.21 & 11.77 & 21.08 & 22 \\
\hline & C. minutum & 311.0 & 180 & 399 & 309 & 56.98 & 12.43 & 18.32 & 21 \\
\hline & C. spatiosum & 209.9 & 166 & 251 & 204 & 34.64 & 13.09 & 16.51 & 11 \\
\hline \multirow[t]{3}{*}{ Body, width/body, length (\%) } & C. curva & 48.2 & 33.3 & 62.6 & 48.6 & 7.40 & 1.66 & 15.36 & 20 \\
\hline & C. minutum & 28.2 & 21.6 & 36.4 & 27.2 & 4.73 & 1.03 & 16.75 & 21 \\
\hline & C. spatiosum & 52.9 & 39.0 & 67.1 & 52.0 & 9.02 & 3.41 & 17.06 & 11 \\
\hline \multirow[t]{3}{*}{ Buccal field, length in vivo $(\mu \mathrm{m})$} & C. curva & 94.1 & 69 & 119 & 92 & 16.03 & 4.83 & 17.03 & 11 \\
\hline & C. minutum & 111.6 & 76 & 138 & 114 & 15.88 & 3.64 & 14.23 & 19 \\
\hline & C. spatiosum & 157.8 & 110 & 200 & 150 & 30.09 & 7.09 & 19.07 & 18 \\
\hline \multirow[t]{2}{*}{ Buccal field, length $(\mu \mathrm{m})$} & C. curva & 92.6 & 63 & 115 & 95 & 13.15 & 3.19 & 14.20 & 17 \\
\hline & C. minutum & 97.7 & 64 & 125 & 100 & 15.61 & 3.41 & 15.98 & 21 \\
\hline \multirow[t]{3}{*}{ Buccal length/body, length in vivo (\%) } & C. curva & 39.3 & 31.7 & 45.8 & 39.7 & 4.60 & 1.39 & 11.71 & 11 \\
\hline & C. minutum & 36.2 & 29.7 & 40.1 & 36.4 & 2.95 & 0.68 & 8.14 & 19 \\
\hline & C. spatiosum & 23.8 & 16.0 & 40.0 & 23.1 & 5.75 & 1.35 & 24.10 & 18 \\
\hline \multirow[t]{2}{*}{ Buccal length/body, length (\%) } & C. curva & 33.7 & 26.9 & 43.9 & 32.6 & 4.44 & 1.11 & 13.20 & 16 \\
\hline & C. minutum & 31.9 & 23.5 & 40.4 & 30.1 & 4.78 & 1.04 & 14.99 & 21 \\
\hline \multirow[t]{3}{*}{ Macronuclear nodules, number } & C. curva & 8.2 & 5 & 11 & 8.5 & 2.32 & 0.95 & 28.37 & 6 \\
\hline & C. minutum & 15.8 & 12 & 20 & 16 & 2.62 & 0.68 & 16.61 & 15 \\
\hline & C. spatiosum & 18.5 & 11 & 25 & 19 & 4.27 & 1.29 & 23.05 & 11 \\
\hline \multirow[t]{3}{*}{ Adoral membranelles, number } & C. curva & 101.2 & 80 & 112 & 104 & 9.15 & 2.54 & 9.04 & 13 \\
\hline & C. minutum & 92.4 & 82 & 107 & 93 & 7.79 & 1.89 & 8.43 & 17 \\
\hline & C. spatiosum & 126.5 & 111 & 144 & 126 & 8.93 & 2.83 & 7.06 & 10 \\
\hline \multirow[t]{3}{*}{ Frontal cirri, number } & C. curva & 5.1 & 4 & 8 & 5 & 1.12 & 0.31 & 21.97 & 13 \\
\hline & C. minutum & 1.0 & 1 & 1 & 1 & 0.00 & 0.00 & 0.00 & 18 \\
\hline & C. spatiosum & 2.0 & 2 & 2 & 2 & 0.00 & 0.00 & 0.00 & 10 \\
\hline \multirow[t]{3}{*}{ Somatic kineties, number } & C. curva & 33.8 & 22 & 38 & 36 & 4.13 & 0.95 & 12.19 & 19 \\
\hline & C. minutum & 40.3 & 38 & 44 & 40 & 1.98 & 0.70 & 4.92 & 8 \\
\hline & C. spatiosum & 59.1 & 49 & 74 & 57 & 7.78 & 2.01 & 13.16 & 15 \\
\hline Paroral membrane, length $(\mu \mathrm{m})$ & C. minutum & 77.6 & 47 & 94 & 80 & 14.94 & 5.28 & 19.24 & 8 \\
\hline
\end{tabular}

Data based on impregnated specimens except body length, width and buccal field length in vivo.

Mean, arithmetic mean; Min, minimum; Max, maximum; Med, median; SD, standard deviation; SE, standard error; CV, coefficient of variation in \%; $n$, number of specimens investigated.

collected from Russia. We compared the Korean and the Russian populations those are slightly different in contractile vacuole (absent vs. present) and body size (210-285 $\mu \mathrm{m}$ vs. 120-200 $\mu \mathrm{m}$ ). However, Song et al. (2003) mentioned that the presence of the contractile vacuole in Burkovsky (1970) was a food vacuole. The Chinese populations of Song et al.(2003) actually corresponded to the Korean population of $C$. curva in terms of all morphological key characters (Table 2, Fig. $7 \mathrm{C}-\mathrm{F})$.

The descriptions of the two populations of Condylostoma arenarium sensu Kahl (1932) and Dragesco and DragescoKernéis (1986) are in agreement with $C$. curva. The one of Kahl's populations is similar to $C$. curva in the body size, body shape, shape of cortical granules, 4-5 frontal cirri and being from a brackish habitat. The African population of Dragesco and Dragesco-Kernéis is similar to $C$. curva in the body shape and the buccal field ratio (Fig. 7A, B) (Kahl, 1932; Dragesco and Dragesco-Kernéis, 1986; Song et al., 2003).

Condylostoma curva Burkovsky, 1970 differs from C. magnum Spiegel, 1926, C. spatiosum Ozaki and Yagiu in Yagiu, 

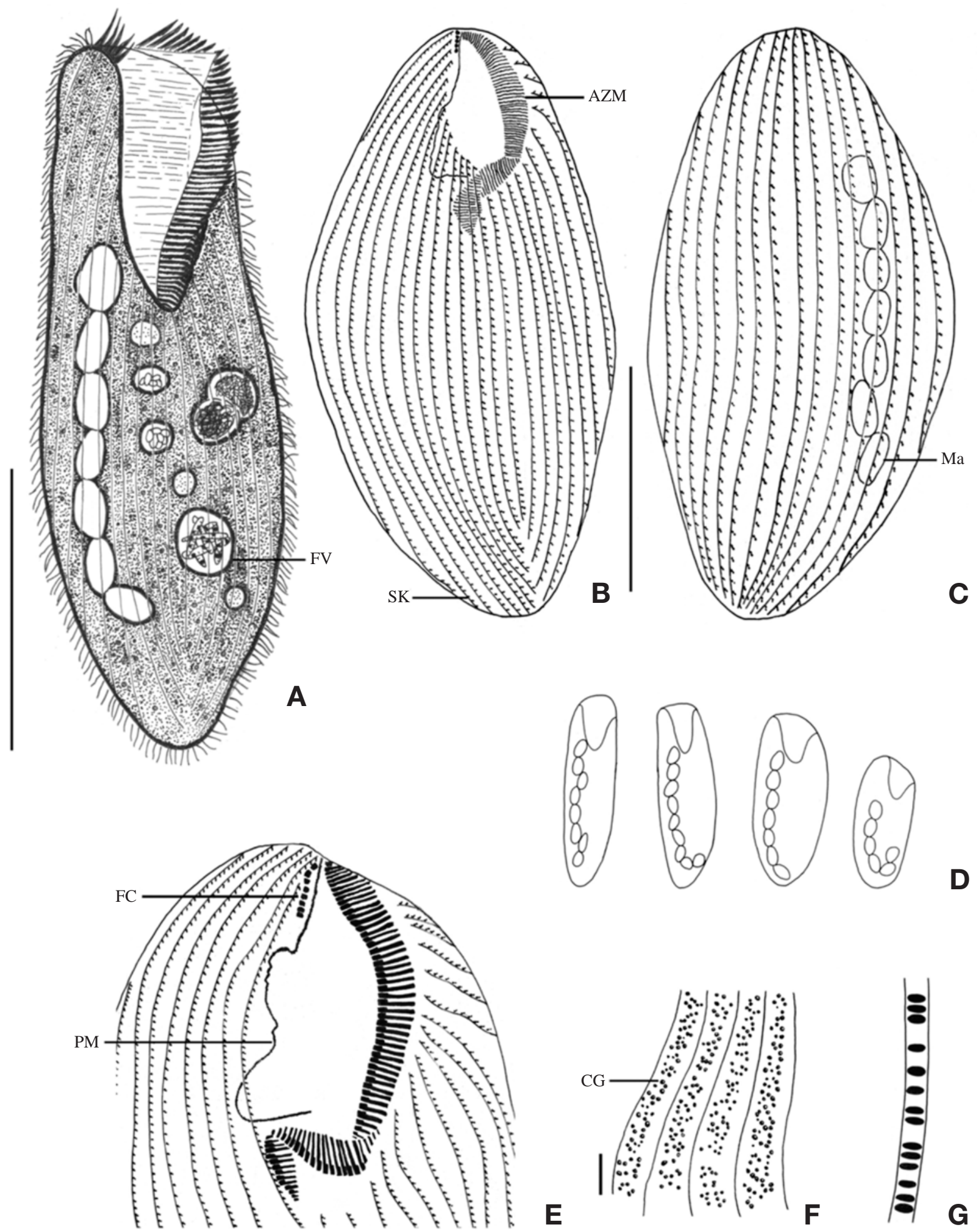

D

Fig. 1. Morphology and infraciliature of Condylostoma curva from live specimens $(A, D, F, G)$ and after protargol impregnation (B, $C$, E). A, Ventral view of a typical individual; $B$, Ventral view of impregnated specimen; C, Dorsal view of impregnated specimen; $D$, Varied body shapes and macronuclear patterns; $E$, Ventral view of buccal field; $F$, Pattern of cortical granules; $G$, Lateral view of cortical granules. AZM, adoral zone of membranelles; CG, cortical granule; FC, frontal cirrus; FV, food vacuole; Ma, macronucleus; PM, paroral membrane; SK, somatic kineties. Scale bars: $A, C=100 \mu \mathrm{m}, F=5 \mu \mathrm{m}$. 

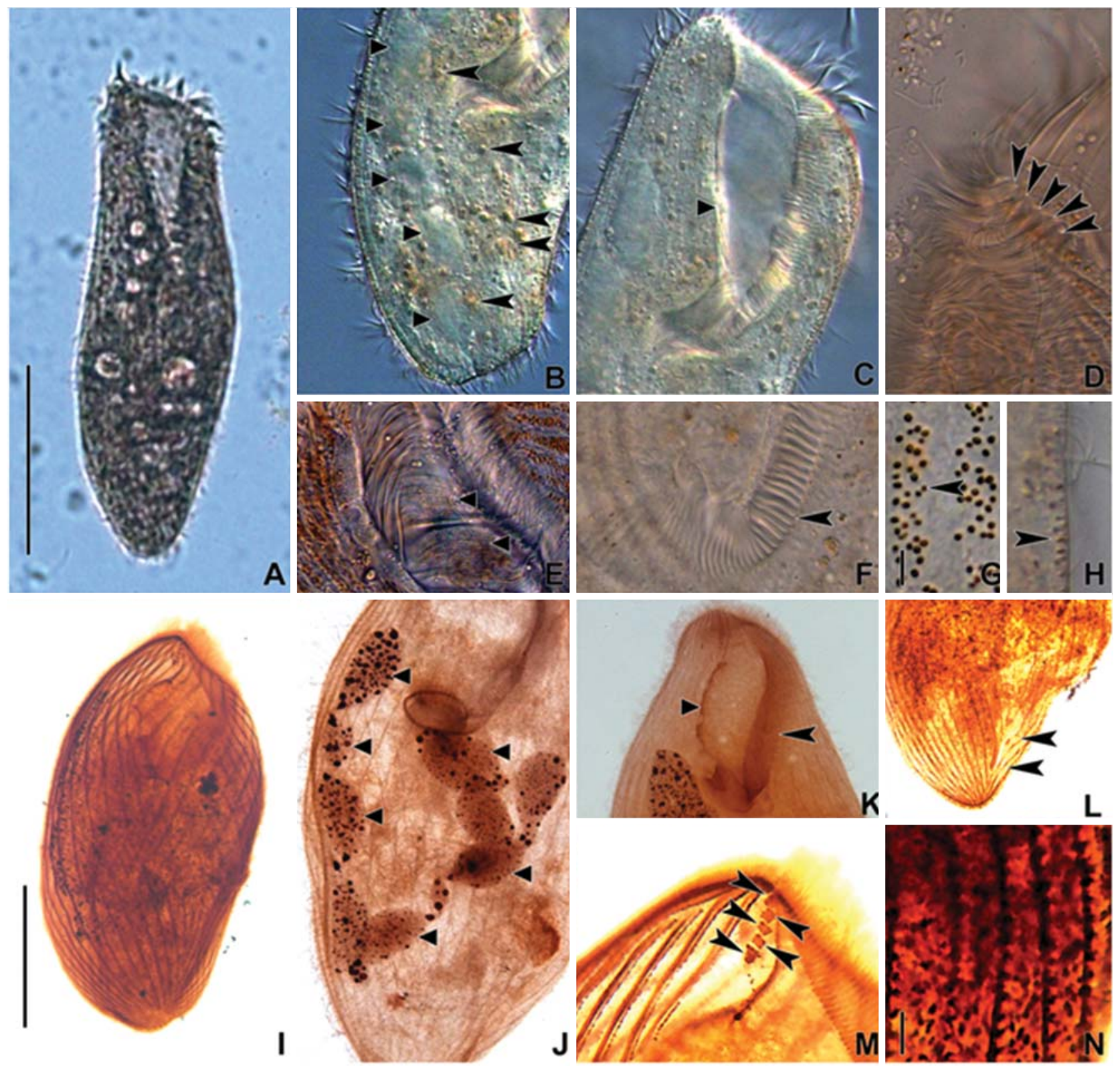

Fig. 2. Microphotographs of Condylostoma curva from live specimens $(A-H)$ and after protargol impregnation (I-N). A, Ventral view of a typical individual; B, Moniliform macronuclear nodules (triangular arrowheads) and cytoplasmic inclusion (arrowheads); C, Buccal field (triangular arrowhead); D, Frontal cirri (arrowheads); E, Buccal field to indicate the stripes of inner wall (triangular arrowheads); $\mathrm{F}$, Proximal end of adoral zone of membranelles (arrowhead); G, Pattern of cortical granules (arrowhead); $\mathrm{H}$, Lateral view of cortical granules (arrowhead); I, Ventral side view; J, Impregnated macronuclear nodules (triangular arrowheads); $\mathrm{K}$, Paroral membrane (triangular arrowhead) and adoral zone of membranelles (arrowhead); L, Suture (arrowheads); M, Frontal cirri (arrowheads); N, Impregnated cortical granules. Scale bars: $A, I=100 \mu \mathrm{m}, \mathrm{G}, \mathrm{N}=5 \mu \mathrm{m}$.

1944 and C. granulosum Bullington, 1940 in body length in vivo $(210-285 \mu \mathrm{m}$ vs. $200-400 \mu \mathrm{m}$ vs. $400-800 \mu \mathrm{m}$ vs. $400-$ $700 \mu \mathrm{m})$, number of frontal cirri (4-8 vs. 1-2 vs. 2 vs. 2 vs. 1 3 ), number of adoral membranelles (80-112 vs. $150-200$ vs. 113-153 vs. 123-210) (Petz et al., 1995; Song and Wilbert, 1997; Song et al., 2003). Condylostoma curva is similar to $C$. minutum Bullington, 1940 and C. arenarium Spiegel, 1926 in body length in vivo, number of somatic kineties, number of macronuclei. However, C. curva and C. minutum are different in number of frontal cirri (4-8 vs. 1-2); $C$. curva differs from $C$. arenarium in number of adoral membranelles (80112 vs. 60-70) (Borror, 1963; Chen et al., 2007). 


\section{1*Condylostoma minutum Bullington, 1940}

(Table 1, Figs. 3, 4)

Condylostoma minutum Bullington, 1940: 193; Chen et al., 2007: 299.

Material examined. Twenty living and 21 protargol impregnated specimens were observed respectively and analyzed biometrically.

Diagnosis. Body size about $315 \times 55 \mu \mathrm{m}$ in vivo, elongated ellipsoidal shaped, buccal cavity about $35 \%$ of body length, macronucleus moniliform with 12-20 nodules, 82-107 adoral membranelles, 1 frontal cirrus, 38-44 somatic kineties.

Description. Body size $265-390 \times 45-70 \mu \mathrm{m}$, usually about
$315 \times 55 \mu \mathrm{m}$ in vivo (Table 1 ). Shape elongated ellipsoidal, dorsoventrally slightly flattened, anterior end truncated and slanted left side, posterior end gradually tapered and narrowly rounded, widest in mid-body (Figs. 3A, C, 4A). Oral cavity fairly deep with transversely striated inner wall (Fig. 4A, G). Macronucleus aligned with the right margin of the body, distinctly nodulated and connected by fine threads, composed of 12-20 usually 16 nodules with many small nucleoli, anterior-most macronuclear nodule size about $28 \times 18 \mu \mathrm{m}$ in protargol impregnated preparations (Figs. 3A, G, 4B, J). No contractile vacuole. Cortex very flexible and contractile. Greenish yellow ellipsoidal cortical granules size about $1 \mu \mathrm{m}$, arranged irregular rows in between kineties (Figs. 3D, E, 4F,

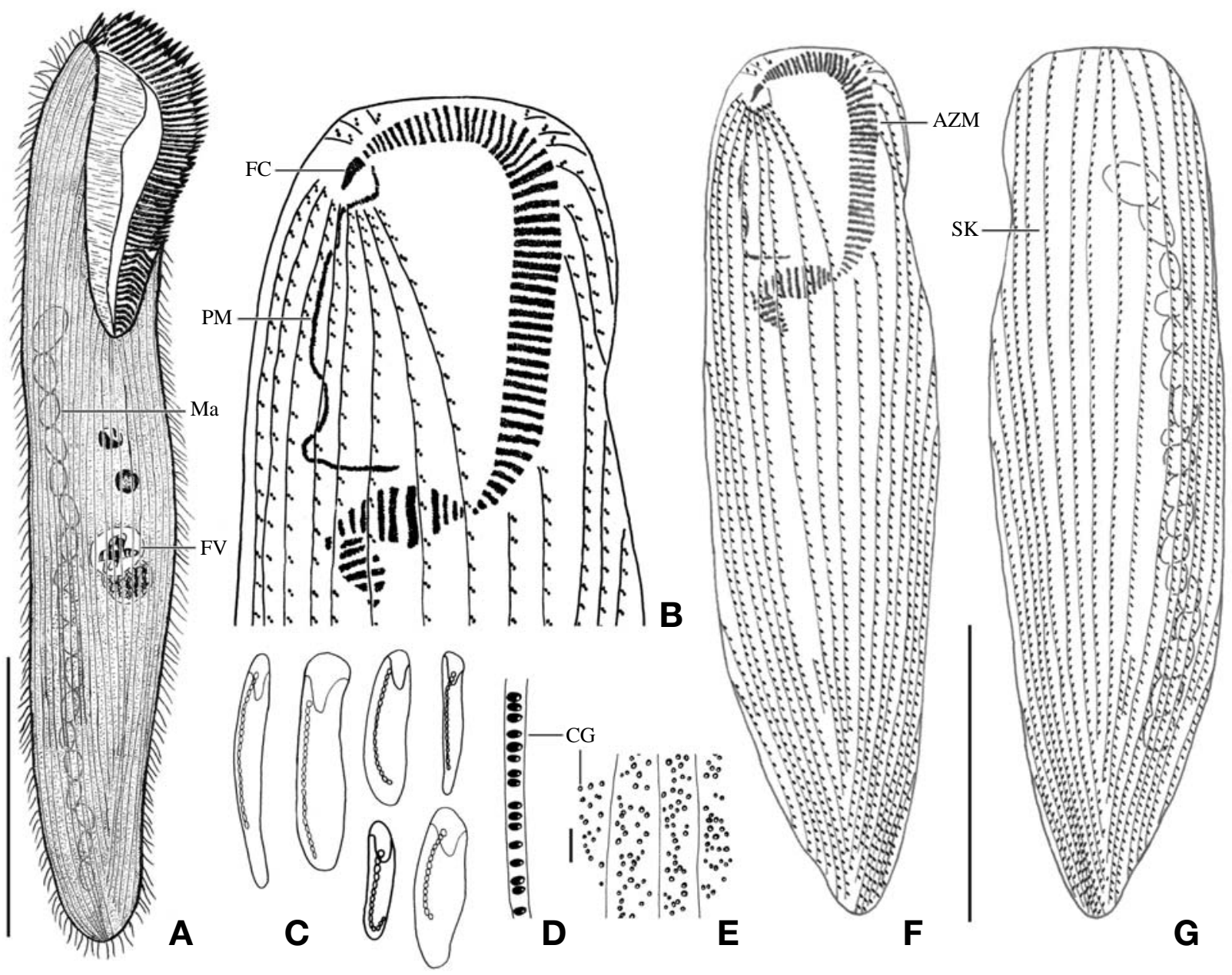

Fig. 3. Morphology and infraciliature of Condylostoma minutum from live specimens $(A, C-E)$ and after protargol impregnation (B, $F$, $\mathrm{G})$. A, Ventral view of a typical individual; B, Ventral view of buccal field; $C$, The various body shape and macronuclear nodules pattern; D, Lateral view of cortical granules; E, Ventral view of cortical granules; F, Ventral view of impregnated specimen; G, Dorsal view of impregnated specimen. AZM, adoral zone of membranelles; CG, cortical granule; FC, frontal cirrus; FV, food vacuole; Ma, macronucleus; PM, paroral membrane; SK, somatic kineties. Scale bars: $A, G=100 \mu \mathrm{m}, E=5 \mu \mathrm{m}$. 

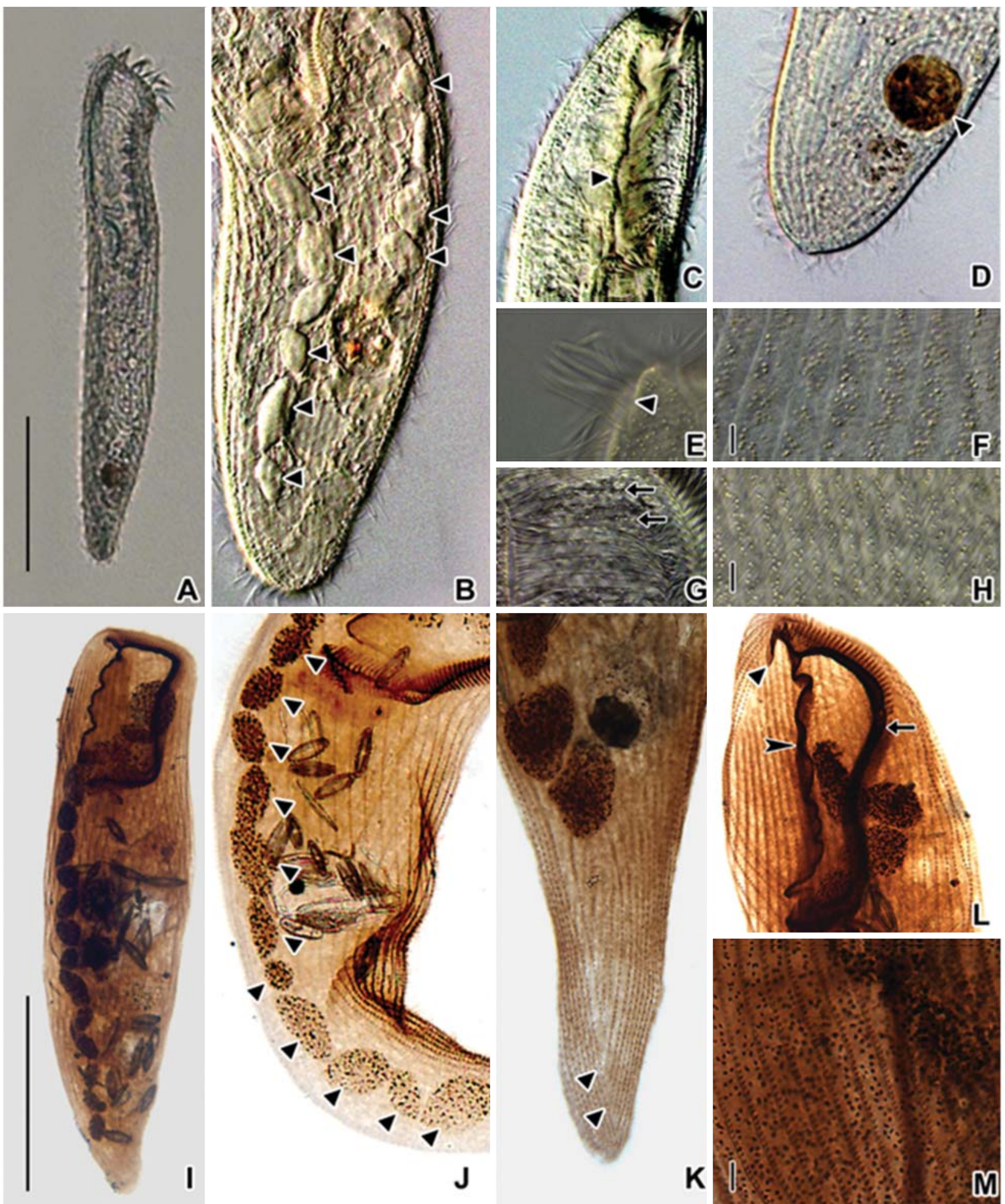

Fig. 4. Microphotographs of Condylostoma minutum from live specimens $(\mathrm{A}-\mathrm{H})$ and after protargol impregnation (I-M). A, Ventral view of a typical individual; $B$, Moniliform macronuclear nodules (trianglular arrowheads); C, Paroral membrane (trianglular arrowhead); D, Food vacuole (trianglular arrowhead); E, Frontal cirrus (trianglular arrowhead); F, H, Cortical granules; G, Striated inner wall on buccal cavity (arrows); I, Ventral side view; J, Moniliform macronucleus (trianglular arrowheads); K, Suture of posterior end (trianglular arrowheads); L, To show adoral zone of membranelles (arrow), frontal cirrus (trianglular arrowhead), paroral membrane (arrowhead); M, Impregnated cortical granules between somatic kineties. Scale bars: $A, I=100 \mu m, F, H, M=5 \mu m$. 
H, M). Cytoplasm colorless with some food vacuoles (Figs. 3A, 4D). Movement moderately slow, usually gliding on bottom.

Somatic kineties arranged longitudinally 38-44 rows, usually commenced near the buccal field, formed suture posteriorly, consisted of dikinetids and somatic cilia about $10 \mu \mathrm{m}$ long in vivo (Figs. 3F, G, 4K). One frontal cirrus near apical end of right margin, on outside of buccal cavity and 15-20 $\mu \mathrm{m}$ long in vivo (Figs. 3A, B, F, 4E, L).

The adoral zone of membranelles conspicuously covered the left side of the buccal field, occupied $30-40 \%$ of the body length, with the proximal portion extending spirally into the cytopharynx, consisting of 82-107 adoral membranelles (Figs. 3A, B, F, 4A, I, L). The paroral membrane located on the inner side of the buccal cavity, total length $47-94 \mu \mathrm{m}$ in impregnated preparations, conspicuously long and smoothly undulated with a cilia about $25 \mu \mathrm{m}$ in length in vivo (Figs. 3B, 4C).

Distribution. Asia (China, Korea), South America (Mexico). Remarks. The Korean population of Condylostoma minutum closely resembles the Gulf of Mexico and Chinese populations of it with respect to body size, number of fragments of the macronucleus, number of adoral membranelles, ratio of adoral zone of membranelles. However, this Korean population differs from the Chinese population in number of somatic kineties (38-44 vs. 26-33) and number of frontal cirri (1 vs. 1-2) (Table 2, Fig. 7G-I) (Bullington, 1940; Chen et al., 2007).

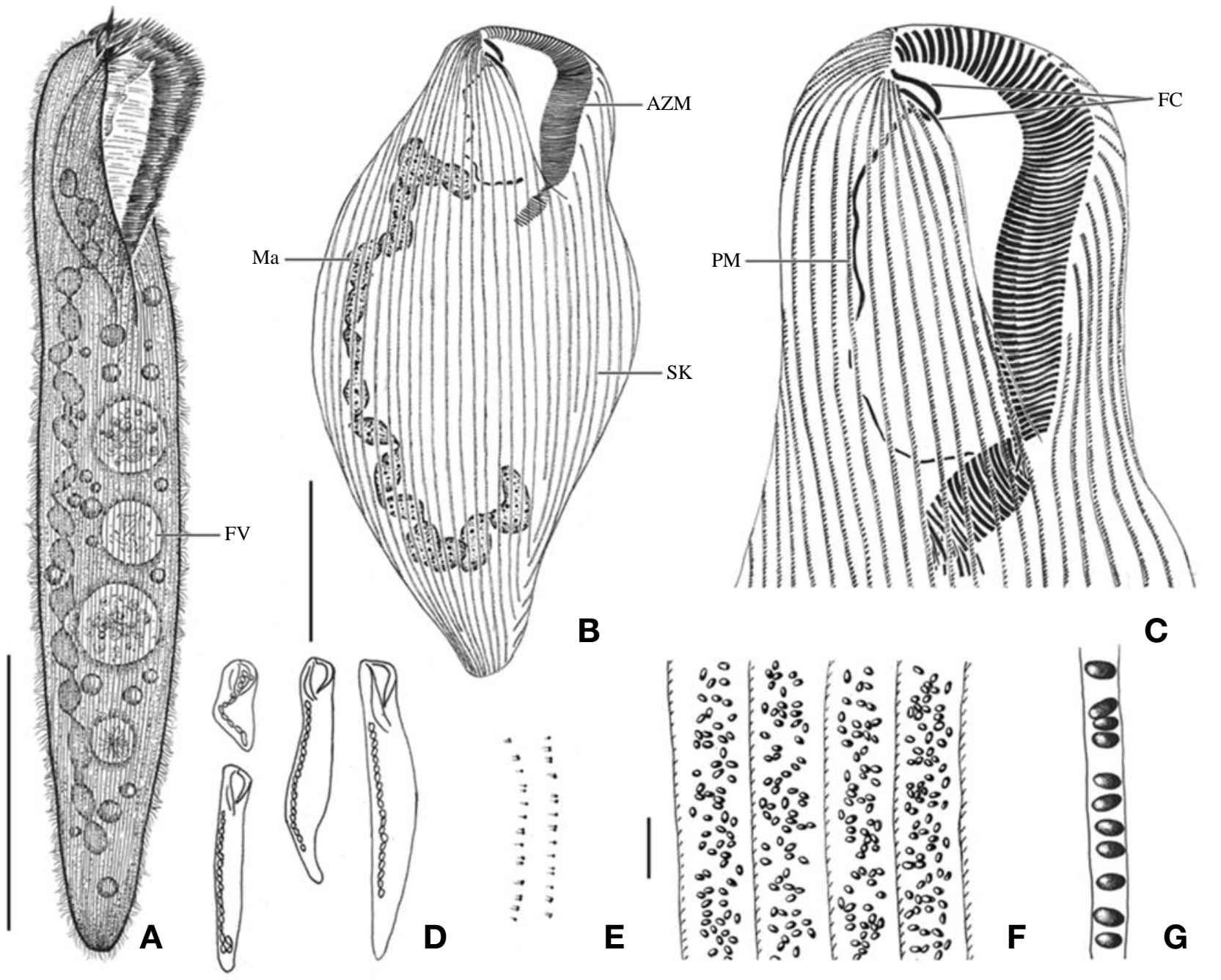

Fig. 5. Morphology and infraciliature of Condylostoma spatiosum from live specimens (A, D-G) and after protargol impregnation (B, C). A, Ventral view of a typical individual; B, Ventral view of impregnated specimen; C, Ventral view of buccal field; $D$, Various body shape and macronuclear nodules pattern; $E$, Infraciliature of somatic dikinetids; $F$, Pattern of cortical granules; G, Lateral view of cortical granules. AZM, adoral zone of membranelles; FC, frontal cirrus; FV, food vacuole; Ma, macronucleus; PM, paroral membrane; SK, somatic kineties. Scale bars: $A=200 \mu \mathrm{m}, B=100 \mu \mathrm{m}, F=5 \mu \mathrm{m}$. 
Condylostoma minutum differs from $C$. magnum and $C$. spatiosum in body length in vivo (265-390 $\mu \mathrm{m}$ vs. $400-800$ $\mu \mathrm{m}$ vs. $400-700 \mu \mathrm{m})$, number of frontal cirri (1 vs. 2 vs. 2 ), number of somatic kineties (38-44 vs. 47-56 vs. 51-63), number of adoral membranelles (82-107 vs. $150-200$ vs. 113-153) (Song and Wilbert, 1997; Chen et al., 2007).

\section{$1 *$ Condylostoma spatiosum Ozaki and Yagiu in Yagiu, 1944 (Table 1, Figs. 5, 6)}

Condylostoma spatiosum Ozaki and Yagiu in Yagiu, 1944: 163; Shao et al., 2006: 11; Chen et al., 2007: 306; Wilbert and Song, 2008: 990.

Material examined. Eighteen living and 11 protargol impregnated specimens were observed respectively and analyzed biometrically.
Diagnosis. Body size about $670 \times 105 \mu \mathrm{m}$ in vivo, elongated ellipsoidal shaped, buccal cavity about $25 \%$ of body length, macronucleus moniliform with 11-25 nodules, 111-144 adoral membranelles, 2 frontal cirri, 49-74 somatic kineties.

Description. Body size of 480-800 $\times 80-130 \mu \mathrm{m}$, usually about $670 \times 105 \mu \mathrm{m}$ in vivo (Table 1 ). Shape elongated ellipsoidal, dorsoventrally slightly flattened, anterior end truncated and slanted left side, posterior end gradually tapered and narrowly rounded, body margin slightly parallel (Figs. 5A, D, 6A). Oral cavity fairly deep with transversely striated inner wall (Figs. 5A, 6C). Macronucleus aligned usually with the right margin of the body, distinctly nodulated and connected by threads, composed of 11-25 usually 19 nodules with many small nucleoli in impregnated preparations (Figs. $5 \mathrm{~A}, \mathrm{~B}, 6 \mathrm{~B}, \mathrm{~J})$. No contractile vacuole. Cortex very flexible and contractile. Slightly yellowish ellipsoidal cortical gran-

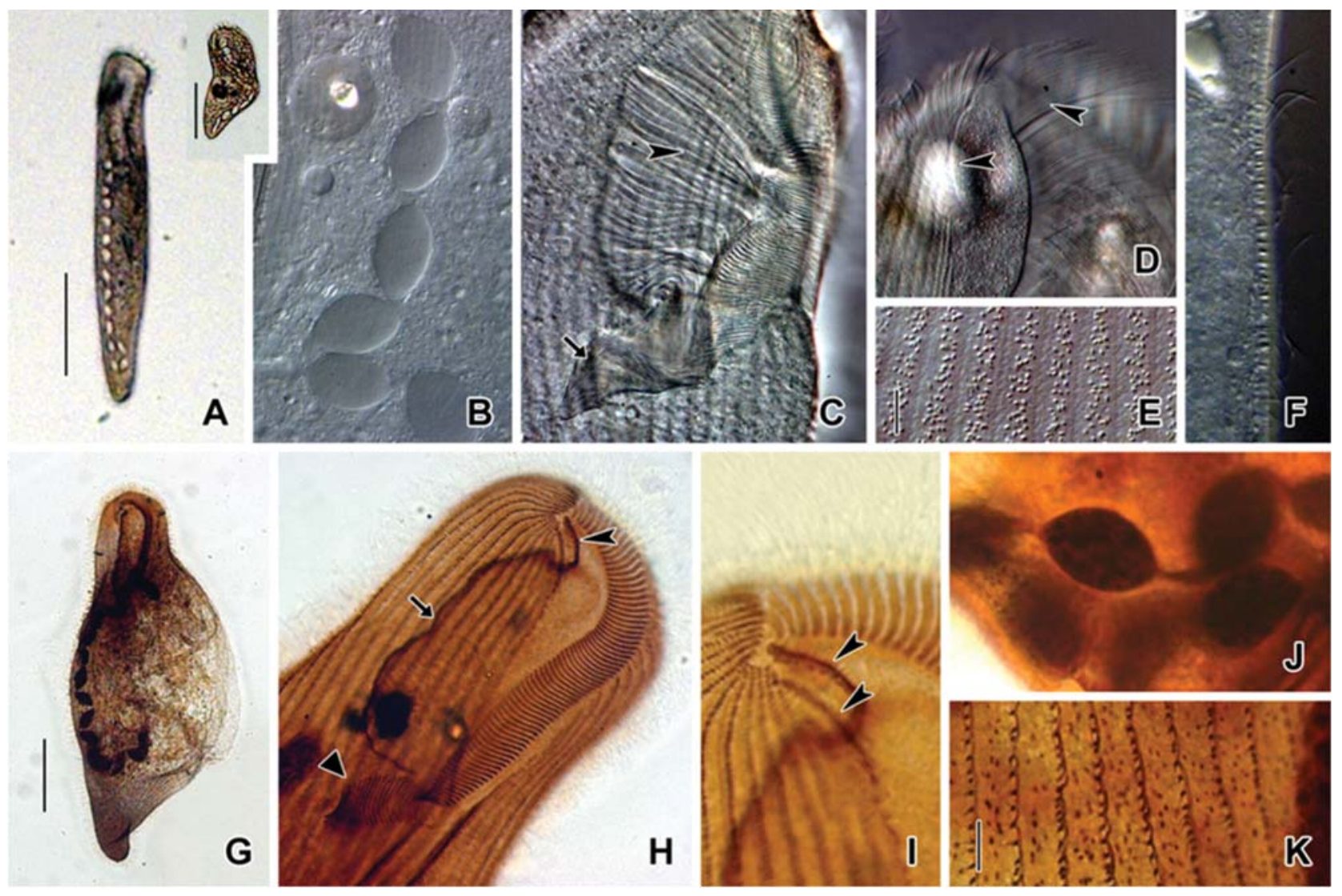

Fig. 6. Microphotographs of Condylostoma spatiosum from live specimens (A-F) and after protargol impregnation (G-K). A, Ventral side view; B, Moniliform macronuclear nodules; C, Buccal field to indicate the stripes of inner wall (arrowhead) and the cytopharynx (arrow); D, Location of frontal cirri (arrowheads); E, Pattern of cortical granules; F, Lateral view of cortical granules; G, Ventral side view in impregnated specimen; $\mathrm{H}$, Ventral view of frontal cirri (arrowhead), paroral membrane (arrow) and cytopharynx (triangular arrowhead); I, Location of frontal cirri (arrowheads); J, Macronuclear nodules and threads; $\mathrm{K}$, Cortical granules in impregnated specimen. Scale bars: $A=200 \mu \mathrm{m}$, Inset in $A=200 \mu \mathrm{m}, E, K=5 \mu \mathrm{m}, \mathrm{G}=100 \mu \mathrm{m}$.

Korean name: ${ }^{1 *}$ 넓은터진입섬모충 

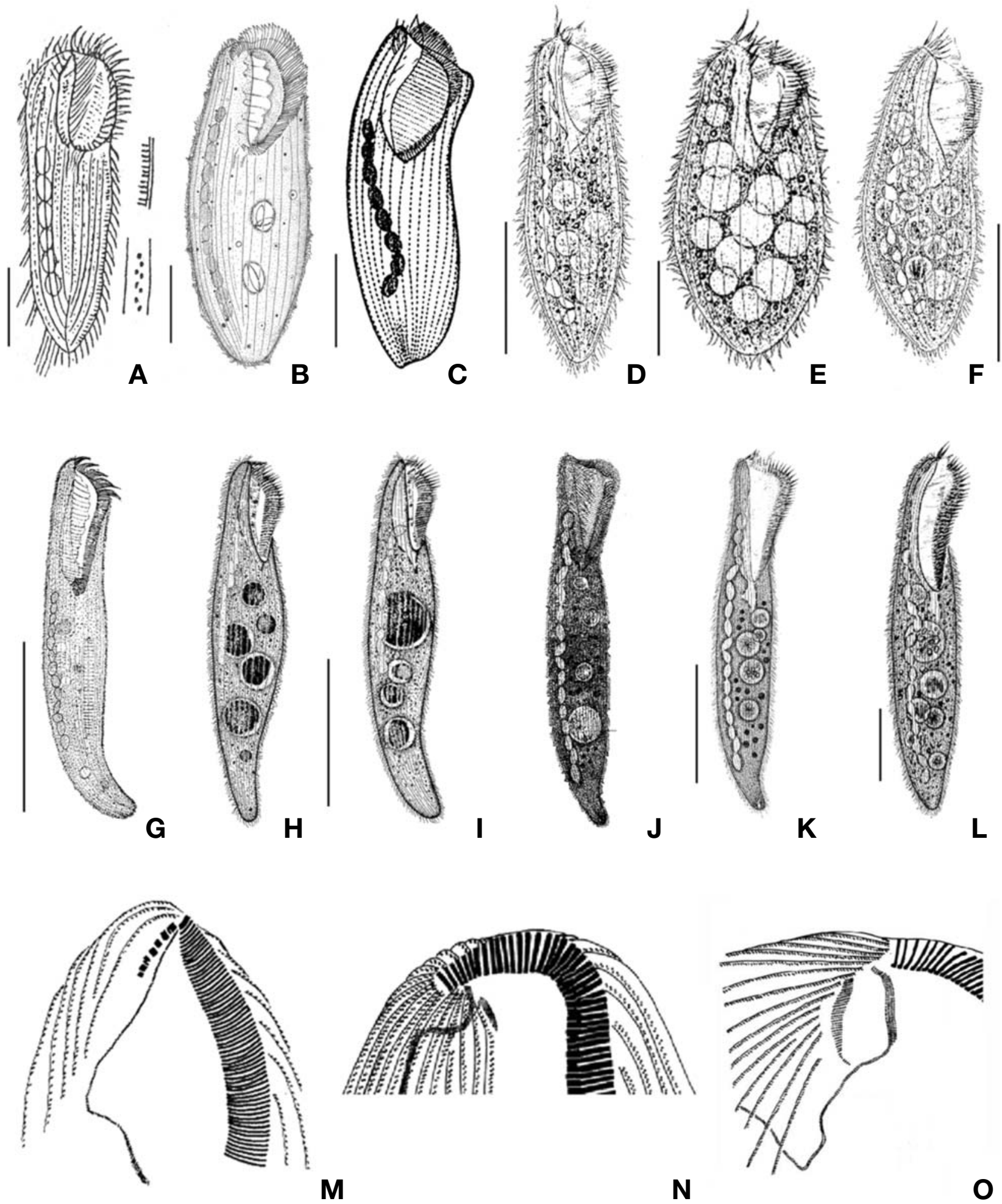

Fig. 7. A-F, M, Condylostoma curva Burkovsky, 1970 (A, from Kahl, 1932; B, from Dragesco J, Dragesco-Kernéis A, 1986; C, from Burkovsky, 1970; D-F, from Song et al., 2003); M, The apparatus of frontal cirri (from Song et al., 2003); G-L, N, C. minutum Bullington, 1940 (G, from Bullington, 1940; H, I, Chen et al., 2007); N, The apparatus of frontal cirrus (from Chen et al., 2007); JL, O, C. spatiosum Ozaki and Yagiu in Yagiu, 1944 (J, from Ozaki and Yagiu in Yagiu, 1944; K, L, from Shao et al., 2006); O, The apparatus of frontal cirri (from Chen et al., 2007). Scale bars: $A-C, E, F=50 \mu m, D, G, I, L=100 \mu m, K=200 \mu m$. 
Table 2. Comparisons of previous studies of Condylostoma curva, C. minutum, and C. spatiosum

\begin{tabular}{|c|c|c|c|c|c|c|c|c|c|}
\hline Characters/Species & $\begin{array}{c}\text { C. } \\
\text { curva }\end{array}$ & $\begin{array}{c}C . \\
\text { minutum }\end{array}$ & $\begin{array}{c}\text { C. } \\
\text { spatiosum }\end{array}$ & $\begin{array}{c}\text { C. } \\
\text { curva }\end{array}$ & $\begin{array}{c}\text { C. } \\
\text { curva }\end{array}$ & $\begin{array}{c}C . \\
\text { minutum }\end{array}$ & $\begin{array}{c}C . \\
\text { minutum }\end{array}$ & $\begin{array}{c}\text { C. } \\
\text { spatiosum }\end{array}$ & $\begin{array}{c}\text { C. } \\
\text { spatiosum }\end{array}$ \\
\hline Body, length in vivo $(\mu \mathrm{m})$ & $210-285$ & $265-390$ & $480-800$ & $150-350$ & $120-200$ & $200-400$ & $199-264$ & $400-700$ & $364-1320$ \\
\hline Frontal cirri, number & $4-8$ & 1 & 2 & $4-8$ & 5 & $1-2$ & - & 2 & 3 \\
\hline Somatic kineties, number & $22-38$ & $38-44$ & $49-74$ & $22-32$ & $20-25$ & $26-33$ & $32-40$ & $51-63$ & $47-64$ \\
\hline $\begin{array}{l}\text { Macronuclear nodules, } \\
\text { number }\end{array}$ & $5-11$ & $12-20$ & $11-25$ & $5-13$ & $7-9$ & $10-15$ & ca 13 & $13-22$ & $17-31$ \\
\hline $\begin{array}{l}\text { Adoral membranelles, } \\
\text { number }\end{array}$ & $80-112$ & $82-107$ & $111-144$ & $68-108$ & - & $67-103$ & - & $113-153$ & ca. 80 \\
\hline $\begin{array}{l}\text { Buccal field ratio of } \\
\text { body length }(\%)\end{array}$ & $27-44$ & $20-40$ & $16-40$ & $35-45$ & - & ca 25 & ca 25 & $25-33$ & ca 22 \\
\hline Cytoplasm color & $\begin{array}{l}\text { Yellowish } \\
\text { brown }\end{array}$ & Colorless & Grayish & Yellowish & - & $\begin{array}{l}\text { Yellow- } \\
\text { brownish }\end{array}$ & - & $\begin{array}{l}\text { Yellow- } \\
\text { grayish }\end{array}$ & - \\
\hline Cortical granules & $\begin{array}{l}\text { Ellipsoidal, } \\
\text { dark } \\
\text { greenish } \\
\text { brown }\end{array}$ & $\begin{array}{l}\text { Ellipsoidal, } \\
\text { greenish } \\
\text { yellow }\end{array}$ & $\begin{array}{c}\text { Ellipsoidal, } \\
\text { yellowish } \\
\text { gray }\end{array}$ & $\begin{array}{l}\text { Ellipsoidal, } \\
\text { dark- } \\
\text { grayish }\end{array}$ & - & $\begin{array}{l}\text { Ellipsoidal, } \\
\text { dark- } \\
\text { grayish }\end{array}$ & - & $\begin{array}{l}\text { Ellipsoidal, } \\
\text { dark- } \\
\text { grayish }\end{array}$ & $\begin{array}{c}\text { Pale } \\
\text { yellowish } \\
\text { green }\end{array}$ \\
\hline Data sources & $\begin{array}{l}\text { Present } \\
\text { species }\end{array}$ & $\begin{array}{l}\text { Present } \\
\text { species }\end{array}$ & $\begin{array}{l}\text { Present } \\
\text { species }\end{array}$ & $\begin{array}{c}\text { Song } \\
\text { et al. (2003) }\end{array}$ & $\begin{array}{l}\text { Burkovsky } \\
\text { (1970) }\end{array}$ & $\begin{array}{c}\text { Chen } \\
\text { et al. (2007) }\end{array}$ & $\begin{array}{l}\text { Bullington } \\
\text { (1940) }\end{array}$ & $\begin{array}{c}\text { Shao } \\
\text { et al. (2006) }\end{array}$ & $\begin{array}{l}\text { Yagiu } \\
(1944)\end{array}$ \\
\hline
\end{tabular}

- , data unavailable.

ules about $0.5-0.8 \times 0.7-1.5 \mu \mathrm{m}$ in size and about $1-5$ irregular rows in between kineties (Figs. 5F, G, 6E, F, K). Cytoplasm colorless with some small inclusions $4 \mu \mathrm{m}$ in vivo, lipid-like droplets and occasionally large food vacuoles (Figs. 5A, 6A). Movement moderately slow, usually gliding on bottom.

Somatic kineties arranged longitudinally in 49-74 rows, mostly commenced near the buccal field, formed suture posteriorly, consisted of dikinetids and somatic cilia about $12 \mu \mathrm{m}$ in length in vivo (Fig. 5B, E). Frontal cirri near the apical end of right margin, two membrane-like cirri were located, respectively, on outside of the buccal cavity, about $40 \mu \mathrm{m}$ in length in vivo and on the apical end of the paroral membrane and connected with paroral, about $20 \mu \mathrm{m}$ in length in vivo (Figs. 5C, 6D, H, I, 7O).

The adoral zone of membranelles which conspicuously covered the left side of the buccal field, occupied 16-40\% of the body length, the proximal portion extending spirally into the cytopharynx, consisting of 111-144 adoral membranelles (Figs. 5A, C, 6C, H). The paroral membrane located on the inner side of the buccal cavity in impregnated preparations, was conspicuously long and smoothly undulated (Figs. 5C, $6 \mathrm{H})$.

Distribution. Asia (China, Japan, Korea), Antarctica

Remarks. This Korean population of Condylostoma spatiosum Ozaki and Yagiu in Yagiu, 1944 closely resembles with the Chinese and Japanese populations which have similar characters in body size (480-800 vs. $400-700$ vs. $364-1,320$ ), number of frontal cirri ( 2 vs. 2 vs. 3 ), and number of somatic kineties (49-74 vs. 51-63 vs. 47-64). The number of adoral membranelles is conspicuously less than the others in the Japanese population. The colors of cortical granules are different (Korean, yellowish gray; Chinese, dark gray; Japanese, yellowish green). However, this can be a variable character because it is depends on the subjective or the microscopic field. The Korean population has a variation in the pattern of cortical granules dense or loose (Table 2, Fig. 7J-L) (Yagiu, 1944; Shao et al., 2006; Chen et al., 2007).

This present species is different from the Condylostoma magnum Spiegel, 1926 in number of adoral membranelles (111-144 vs. 150-200) (Song and Wilbert, 1997; Shao et al., 2006).

\section{ACKNOWLEDGMENTS}

This study was supported by the grant from the National Research Foundation of Korea Grant funded by the Korea Government (No. 2009-0077263), and "The Survey of Korean Indigenous Species" supported by the National Institute of Biological Resources (NIBR) of Korea.

\section{REFERENCES}

Al-Rasheid KAS, 1999. Records of marine interstitial Heterotrichida (Ciliata) from the Saudi Arabian Jubail marine wildlife 
sanctuary in the Arabian Gulf. Arab Gulf Journal of Scientific Research, 17:127-141.

Bock KJ, 1955. Condylostoma vastum nov. spec., und Aspidisca pertinens nov. spec., zwei sandbewohnende Ciliaten aus dem Küstengebiet der Kieler Bucht. Zoologischer Anzeiger, 154:302-304.

Borror AC, 1963. Morphology and ecology of the benthic ciliated protozoa of Alligator Harbor, Florida. Archiv für Protistenkunde, 106:465-534.

Bullington WE, 1940. Some ciliates from Tortugas. Papers from the Tortugas Laboratory of the Carnegie Institution of Washington, 32:179-222.

Burkovsky IV, 1970. The ciliates of the mesopsammon of the Kandalaksha Gulf (White Sea). II. Acta Protozoologica, 8: 47-64.

Carey PG, 1992. Marine interstitial ciliates: an illustrated key. Champman and Hall, London, pp. 1-351.

Chen X, Song W, Al-Rasheid KAS, Warren A, Long H, Shao C, Al-farraj SA, Gong J, Hu X, 2007. The morphology of three marine heterotrichous ciliaes, Condylostentor auriculatus (Kahl, 1932) Jankowski, 1978, Condylostoma minutum Bullington, 1940 and C. spatiosum Ozaki \& Yagiu in Yagiu, 1944 (Ciliophora: Heterotrichida). Acta Protozoologica, 46: 289-309.

Dragesco J, 1960. Ciliés mésopsammiques littoraux: systématique, morphologie, écologie. Travaux de la Station Biologique de Roscoff, 12:1-356.

Dragesco J, Dragesco-Kernéis A, 1986. Ciliés libres de l'Afrique intertropicale: introduction á la connaissance et á l'étude des ciliés. Faune Tropicale, 26:1-559.

Fauré-Fremiet E, 1958. Le cilie condylostoma tenuis n. sp. et son algue symbiote. Hydrologica, 10:43-48.

Foissner W, 1992. Protargol methods. In: Protocols in protozoology (Eds., Lee JJ, Soldo AT). The Society of Protozoologists, Allen Press, Lawrence, KS, p. C 6.1-C 6.8.

Foissner W, 1995. Tropical protozoan diversity: 80 ciliate species (Protozoa, Ciliophora) in a soil sample from a tropical dry forest of Costa Rica, with descriptions of four new genera and seven new species. Archiv für Protistenkunde, 145: 37-79.

Foissner W, Berger H, Schaumberg J, 1999. Identification and ecology of limnetic plankton ciliates. Informationsberichte des Bayer. Landesamtes für Wasserwirtschaft, 3/99:1-793.

Hartwig E, 1973. The ciliates of the tidal beach on the island
Sylt (North Sea) I. Systematic. Mikrofauna Meeresboden, 18:387-453.

Kahl A, 1932. Urtiere oder Protozoa. I: Wimpertiere oder Ciliata (Infusoria). 3. Spirotricha. Die Tierwelt Deutschlands, 25: 399-650.

Lynn DH, 2008. The ciliated protozoa: characterization, classification, and guide to the literature. 3rd ed. Springer Publishers, New York, pp. 1-605.

Petz W, Song W, Wilbert N, 1995. Taxonomy and ecology of the ciliate fauna (Protozoa, Ciliophora) in the endopagial and pelagial of the Weddell Sea, Antarctica. Stafia, 40:1223.

Shao C, Song W, Hu X, Ma H, Zhu M, Wang M, 2006. Cell division and morphology of the marine ciliate, Condylostoma spatiosum Ozaki and Yagiu (Ciliophora, Heterotrichida) based on a Chinese population. European Journal of Protistology, 42:9-19.

Song W, Warren A, Ji D, Wang M, Al-Rasheid KAS, 2003. New contributions to two heterotrichous ciliates, Folliculina simplex (Dons, 1917), Condylostoma curva Burkovsky, 1970 and one licnophorid, Licnophora lyngbycola Fauré-Fremiet, 1937 (Protozoa, Ciliophora): descriptions of morphology and infraciliature. Journal of Eukayotic Microbiology, 50: 449-462.

Song W, Wilbert N, 1997. Morphological investigations on some free living ciliates (Protozoa, Ciliophora) from China Sea with description of a new hypotrichous genus, Hemigastrostyla nov. gen. Archiv für Protistenkunde, 148:413-444.

Villeneuve-Brachon S, 1940. Recherches sur les ciliés hétérotriches: Cinétome, argyrome, myonèmes. Formes nouvelles ou peu connues. Archives de Zoologie Experimentale et Generale, 82:1-180.

Wilbert N, 1975. Eine Verbesserte Technik der Protargolimpragnation für Ciliaten. Mikrokosmos, 64:171-179.

Wilbert N, Song W, 2008. A further study on littoral ciliates (Protozoa, Ciliophora) near King George Island, Antarctica, with description of a new genus and seven new species. Journal of Natural History, 42:979-1012.

Yagiu R, 1944. Studies on the ciliates Condylostoma I: taxonomy. Journal of Science of the Hiroshima University, 10:161184.

Received March 12, 2012

Revised May 22, 2012

Accepted May 25, 2012 